\title{
The Role of Oliguria and the Absence of Fluid Administration and Balance Information in Illness Severity Scores
}

\author{
Neil J. Glassford ${ }^{1,2}$ and Rinaldo Bellomo ${ }^{1,2,3}$ \\ ${ }^{1}$ Department of Intensive Care, Austin Hospital, Melbourne; ${ }^{2}$ Australian and New Zealand Intensive Care Research Centre, School of Public Health and Preventive Medicine, Monash \\ University, Prahran; ${ }^{3}$ School of Medicine, The University of Melbourne, Melbourne, Australia
}

\begin{abstract}
Urinary examination has formed part of patient assessment since the earliest days of medicine. Current definitions of oliguria are essentially arbitrary, but duration and intensity of oliguria have been associated with an increased risk of mortality, and this risk is not completely attributable to the development of concomitant acute kidney injury (AKI) as defined by changes in serum creatinine concentration. The increased risk of death associated with the development of AKI itself may be modified by directly or indirectly by progressive fluid accumulation, due to reduced elimination and increased fluid administration. None of the currently extant major illness severity scoring systems or outcome prediction models use modern definitions of AKI or oliguria, or any values representative of fluid volumes variables. Even if a direct relationship with mortality is not observed, then it is possible that fluid balance or fluid volume variables mediate the relationship between illness severity and mortality in the renal and respiratory physiological domains. Fluid administration and fluid balance may then be an important, easily modifiable therapeutic target for future investigation. These relationships require exploration in large datasets before being prospectively validated in groups of critically ill patients from differing jurisdictions to improve prognostication and mortality prediction.
\end{abstract}

Key Words: fluid balance; illness severity score; intravenous fluid therapy; mortality; oliguria; prediction.

\section{Introduction}

Urinary examination has formed part of patient assessment since the earliest days of medicine. In Classical Greece, Hippocrates identified urinary characteristics and output as being of prognostic significance [1]. In the second century $\mathrm{CE}$, Galen identified them as being a visible indicator of underlying renal function [2]. By the eighth century CE, as described in De urinis by Theophilus, urinary characteristics were being used as a diagnostic aid [3].

In general, the kidney has the ability to produce both very concentrated and very dilute urine to maintain water and electrolyte homeostasis. Fluid intake beyond that required for essential metabolic processes and those losses insensibly deemed "insensible" must be excreted. Fluid accumulation leading to an increasingly positive cumulative fluid balance may occur as a consequence of disordered elimination, as well as excessive administration (Figure 1). For patients in the intensive care unit (ICU), chronic disease, the presenting illness, intercurrent complication, evolving organ dysfunction, therapeutic administration and inadvertent coadministration of fluid, and the neurohormonal milieu of critical illness it-

Received on March 28, 2017 Accepted on May 5, 2017

Correspondence to: Rinaldo Bellomo, Department of Intensive Care, Austin Hospital, 145 Studley Rd, Heidelberg, Melbourne, VIC 3084, Australia

Tel: +61-3-9496-5992, Fax: +61-3-9496-3932, E-mail: Rinaldo.BELLOM0@austin.org.au

*No potential conflict of interest relevant to this article was reported.

(c) This is an Open Access article distributed under the terms of the Creative Commons Attribution Non-Commercial License (http://creativecommons.org/ licenses/by-nc/4.0/) which permits unrestricted non-commercial use, distribution, and reproduction in any medium, provided the original work is properly cited. Copyright (c) 2017 The Korean Society of Critical Care Medicine 


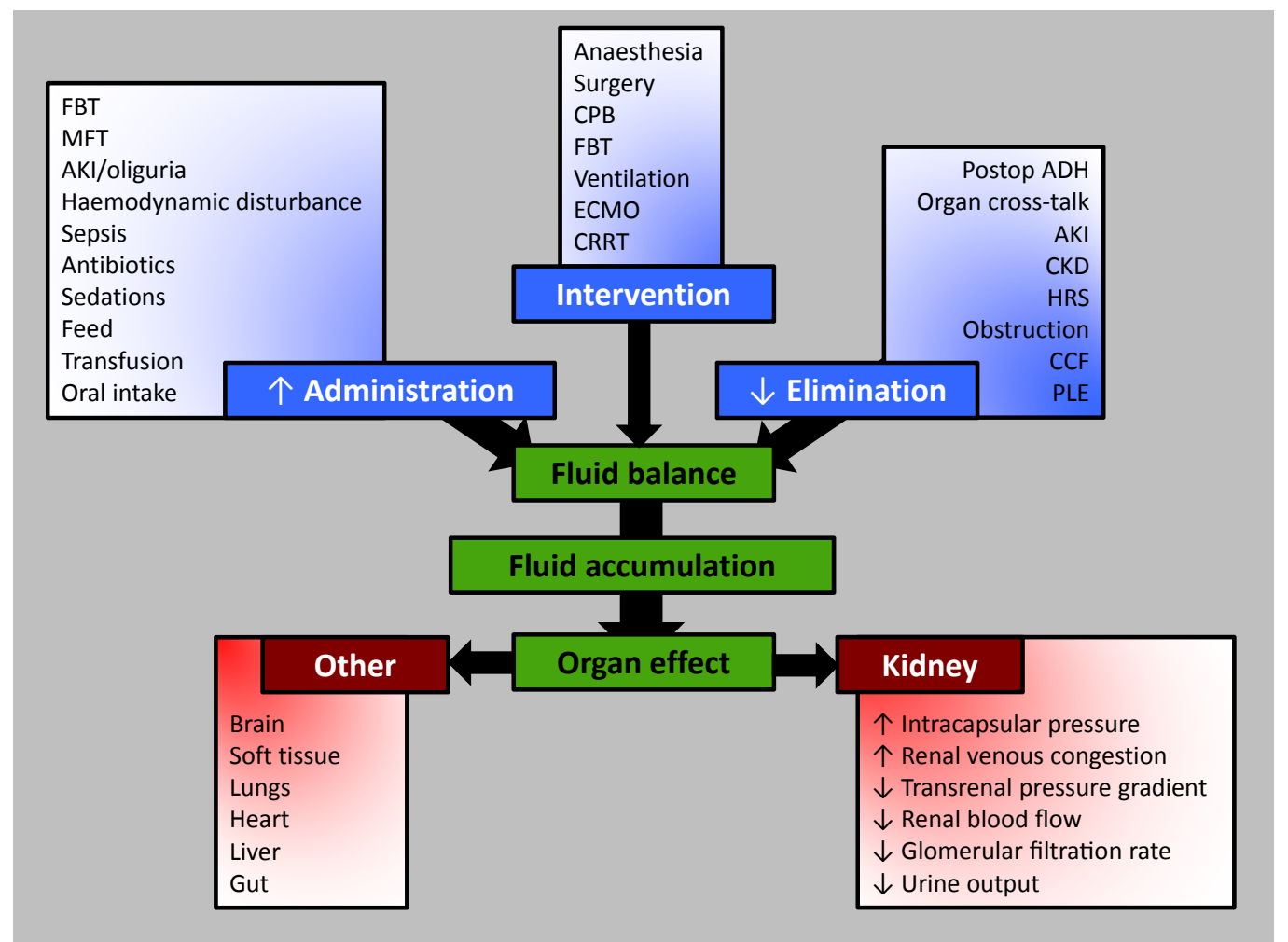

Figure 1. Fluid accumulation in the critically ill. FBT: fluid bolus therapy; MFT: maintenance fluid therapy; AKI: acute kidney injury; CPB: cardiopulmonary bypass; ECMO: extracorporeal membrane oxygenation; CRRT: continuous renal replacement therapy; Postop: postoperative; ADH: antidiuretic hormone; CKD: chronic kidney disease; HRS: hepatorenal syndrome; CCF: chronic cardiac failure; PLE: protein losing enteropathy.

self can make the maintenance of a normal fluid balance almost impossible. At one end of a continuum, oliguria may represent appropriate physiological attempts to conserve salt and water; at the other, it is an easily visualised manifestation of acute kidney injury (AKI).

\section{Historical Definitions of Oliguria}

The modern interpretation of oliguria seems to arise from a series of papers published in the 1930s and 1940s [4]. During water privation studies, urine output (UO) would fall, and urine would become maximally concentrated with respect to urea, creatinine, phosphate, and other waste products at flow rates of less than $0.35-0.5$ $\mathrm{ml}$ per minute [5-7]. Below this level, further reductions in UO were linearly associated with decreasing glomerular filtration rate $[6,8,9]$. While discussed clinically as a concept in educational papers in the early 1950's [1013], it wasn't until the end of that decade that a definition of a total UO of $<700 \mathrm{ml}$ in 24 hours for oliguria, and $<500 \mathrm{ml}$ in 24 hours for severe oliguria, and $<300$ $\mathrm{ml}$ as a threshold for metabolic anuria were found in the literature [14-16]. Studies in the 1960's continued to use absolute measures of UO as indicators of oliguria [17]. From the 1970s [18,19], $400 \mathrm{ml}$ is quoted as the minimum volume of urine required to be produced over a 24-hour period $(0.24 \mathrm{ml} / \mathrm{kg} / \mathrm{h})$ to clear the solute load of normal metabolism in a $70 \mathrm{~kg}$ man; $410 \mathrm{ml} / 24 \mathrm{~h}$ is used as the urinary definition of acute renal failure (ARF) in the Acute Physiology and Chronic Health Evaluation (APACHE) III classification system [20]. Even the most recent discussions of oliguria in critical illness often fail to discuss the derivation of the thresholds of UO defining the term [21].

Weight-based definitions of oliguria appear to arise in 
Table 1. Intensity and severity of oliguria as defined by international guidelines examining acute renal failure and AKI

\begin{tabular}{|c|c|c|c|c|c|c|}
\hline AKI severity & & RIFLE 2004 & & AKIN 2007 & & KDIG0 2012 \\
\hline Mild & Risk & $<5 \mathrm{ml} / \mathrm{kg} / \mathrm{h}$ for $6 \mathrm{~h}$ & Stage 1 & $<5 \mathrm{ml} / \mathrm{kg} / \mathrm{h}$ for $6 \mathrm{~h}$ & Stage 1 & $<5 \mathrm{ml} / \mathrm{kg} / \mathrm{h}$ for $6 \mathrm{~h}$ \\
\hline Moderate & Loss & $<5 \mathrm{ml} / \mathrm{kg} / \mathrm{h}$ for $12 \mathrm{~h}$ & Stage 2 & $<5 \mathrm{ml} / \mathrm{kg} / \mathrm{h}$ for $12 \mathrm{~h}$ & Stage 2 & $<5 \mathrm{ml} / \mathrm{kg} / \mathrm{h}$ for $12 \mathrm{~h}$ \\
\hline Severe & Failure & $\begin{array}{c}<3 \mathrm{ml} / \mathrm{kg} / \mathrm{h} \text { for } 24 \mathrm{~h} \text { or } \\
0 \mathrm{ml} / \mathrm{kg} / \mathrm{h} \text { for } 12 \mathrm{~h}\end{array}$ & Stage 3 & $\begin{array}{c}<3 \mathrm{ml} / \mathrm{kg} / \mathrm{h} \text { for } 24 \mathrm{~h} \text { or } \\
0 \mathrm{ml} / \mathrm{kg} / \mathrm{h} \text { for } 12 \mathrm{~h}\end{array}$ & Stage 3 & $\begin{array}{c}<3 \mathrm{ml} / \mathrm{kg} / \mathrm{h} \text { for } 24 \mathrm{~h} \text { or } \\
0 \mathrm{ml} / \mathrm{kg} / \mathrm{h} \text { for } 12 \mathrm{~h}\end{array}$ \\
\hline
\end{tabular}

AKI: acute kidney injury; RIFLE: Risk, Injury, Failure, Loss, End-Stage Renal Failure; AKIN: Acute Kidney Injury Network; KDIGO: Kidney Disease: Improving Global Outcomes.

the paediatric setting before being translated to adults, though the transition is unclear in the literature $[22,23]$. Until recently, there was little evidence demonstrating an association between specific weight-based UO thresholds and outcome in children and neonates $[24,25]$.

\section{AKI and Intensity and Duration of Oliguria}

UO can be a challenging variable to incorporate into research. Accuracy can be questioned given the normal bedside estimate using visual inspection. Patients may not have indwelling urinary catheters, and so only intermittent outputs may be available. UO may be recorded over a number of hours, rather than hourly, making identification and data handling from electronic sources challenging. It may also be subject to fluctuations as a result of changes in patient haemodynamics, vasoactive medication dosing, diuretic administration or other clinical event $[26,27]$. However, it remains an attractive marker of renal function, despite these limitations. It offers an apparent real time marker of renal function, allowing the natural history of renal dysfunction to be charted - this is of particular importance for the characterisation and calibration of biomarkers of AKI [28]. It requires no knowledge of baseline values to be calculated, unlike changes in serum creatinine ( $\mathrm{sCr}$ ), which is itself an imperfect marker of renal function [26,29].

In 2004, the first consensus definition of ARF was published, based on expert opinion following a meeting of the Acute Dialysis Quality Initiative (ADQI) group [26]. The Risk, Injury, Failure, Loss, End-Stage Renal Disease (RIFLE) classification proposed three categories of oli- guria of increasing intensity and duration, in addition to sCr based definitions of severity (Table 1). These definitions remained consistent across the subsequent revisions of the consensus statements. These included the change in terminology to AKI; the addition of small, $25 \mu \mathrm{mol} / \mathrm{L}$ increases in $\mathrm{sCr}$ defining stage $1 \mathrm{AKI}$ by the Acute Kidney Injury Network (AKIN) guidelines; and adjustments taking into account baseline creatinine in patients with chronic disease. The most recent classifications were published in 2013 in the Kidney Disease: Improving Global Outcomes (KDIGO) guidelines, and presented similar definitions of oliguria [30,31].

While the authors of the ADQI statement acknowledge the arbitrary nature of the weight- and time-based definitions they provide, two important characteristics of oliguria were first discussed: intensity and duration [26]. Intensity refers to the magnitude of the hourly UO, where the lower the volume, the more severe the oliguria. As UO is typically measured hourly, duration refers to the number of hours below the designated intensity threshold. However, in the years since the publication of the original threshold definitions, numerous publications have examined the association between various definitions of oliguria and the subsequent development of AKI.

In a retrospective multi-unit, single-center observational study of 14,524 adult critically ill patients in a US teaching hospital, $57 \%$ of whom developed AKI defined by changes in $\mathrm{sCr}\left(\mathrm{AKI}_{\mathrm{sCr}}\right)$, an attempt was made to validate the urinary criteria of the AKIN definition of AKI [32]. Using complex regression analysis involving all possible combinations of $\mathrm{sCr}$ increase, $\mathrm{UO}$ threshold and oliguria duration, the adjusted mortality and area under the receiver operating curve (AUROC) analysis were 
presented as contour plots. Mortality was demonstrated to rapidly increase as UO decreased below a threshold of $<0.5 \mathrm{ml} / \mathrm{kg} / \mathrm{h}$. Over periods of 5 hours or less with UOs of $<0.3 \mathrm{ml} / \mathrm{kg} / \mathrm{h}$, intensity was particularly important, with risk of death increasing significantly with intensity and duration of oliguria [32].

In a post-hoc analysis of a prospective single-center observational study of 725 adult ICU patients in New Zealand, $21 \%$ postcardiac surgery and $7.7 \%$ with chronic kidney disease (CKD), $72 \%$ of patients developed KDI$\mathrm{GO} \mathrm{AKI}_{\mathrm{sCr}}$ or as defined by $\mathrm{UO}$ criteria $\left(\mathrm{AKI}_{\mathrm{UO}}\right)$ [28]. The optimal UO threshold, collected over 6 hours, predicting a significantly increased risk of death or need for dialysis in this population, was demonstrated to be $0.3 \mathrm{ml} / \mathrm{kg} / \mathrm{h}$. In a complex analysis, the authors offer a time-dependent volume threshold for identifying the intensity of oliguria likely to be associated with subsequent $\mathrm{sCr}$ increase. However, their findings have not been prospectively validated in a suitable cohort, and AUROC for predicting death or dialysis does not significantly increase with increasing duration of oliguria defined in this fashion beyond 6 hours [28].

Duration of oliguria identifying a subsequent high risk of KDIGO $\mathrm{AKI}_{\mathrm{sCr}}$ were explored in a retrospective observational study of 390 adult ICU patients with septic shock, $54.4 \%$ requiring vasopressor support, $25.1 \%$ with KDIGO stage II + AKI and $8.5 \%$ requiring renal replacement therapy (RRT) by 96 hours. On regression analysis in this population, consecutive hours of oliguria, defined as a $U O$ of $<0.5 \mathrm{ml} / \mathrm{kg} / \mathrm{h}$ independently associated with development of KDIGO stage II/III AKI $\mathrm{ACr}_{\mathrm{sc}}$ The sensitivity fell with increasing duration of oliguria over 1-, 3-, and 5-hour periods, though the accuracy and positive predictive value increased [33].

In one of the most detailed examinations of UO thresholds, 2,160 adult ICU patients, $42.8 \%$ with KDIGO AKI and $10.4 \%$ requiring RRT, from 16 Finnish ICUs were prospectively recruited to the Finnish Acute Kidney Injury observational study [34]. In a post-hoc analysis, an independent association was demonstrated between oliguria of differing duration and intensity, where thresholds of $<0.5 \mathrm{ml} / \mathrm{kg} / \mathrm{h},<0.3 \mathrm{ml} / \mathrm{kg} / \mathrm{h}$ and $<0.1 \mathrm{ml} / \mathrm{kg} / \mathrm{h}$ were taken to represent mild, moderate and severe oliguria, and $\mathrm{AKI}_{\mathrm{SCr}}$, after adjusting for age, sex, illness severity, vasoactive or diuretic use, and degree of fluid overload. A similar relationship was demonstrated between oliguria and 90-day mortality after similar adjustment [35].

Oliguria has also been investigated as a predictive biomarker of subsequent $\mathrm{AKI}_{\mathrm{sCr}}$. In a prospective multinational observational study of 239 adult ICU patients, $33.5 \%$ with sepsis $22.5 \%$ developing RIFLE I or worse AKI, and $8.8 \%$ requiring RRT in ICU, oliguria was defined as a $\mathrm{UO}$ of $<0.5 \mathrm{ml} / \mathrm{kg} / \mathrm{h}$. In patients without $\mathrm{AKI}_{\mathrm{sCr}}$ and periods of oliguria, the subsequent risk of $\mathrm{AKI}_{\mathrm{SCr}}$ in the next 24 hours was associated with oliguria of even a single hour's duration. The optimal cutoff, maximising both sensitivity and specificity, was identified as 4 hours on AUROC analysis, though the positive predictive value was only $11 \%$. However, as a screening test, periods of oliguria shorter than 12-hour duration were of limited utility, with likelihood ratios less than 10 for predicting development of $\mathrm{AKI}_{\mathrm{sCr}}$ over 24 hours [4].

While weight-based thresholds of $<0.5 \mathrm{ml} / \mathrm{kg} / \mathrm{h},<0.3$ $\mathrm{ml} / \mathrm{kg} / \mathrm{h}$ and $<0.1 \mathrm{ml} / \mathrm{kg} / \mathrm{h}$ been demonstrated to be of significance as regards the development of $\mathrm{AKI}_{\mathrm{sCr}}$ and predicting subsequent death, at no point has the ability of the empirically derived weight-adjusted thresholds to predict outcome been compared to absolute values of UO. In addition, the relationship between actual and ideal body weight in the calculation of these thresholds remains unexplored.

\section{AKI and Mortality: Dependent on UO?}

Many studies have demonstrated the increased risk of mortality associated with developing $\mathrm{AKI}_{\mathrm{sCr}}$, a risk that increases in magnitude with the severity of the renal dysfunction, and which may persist for 1 or more years following ICU discharge in survivors [36,37]. However, this relationship is complex (Table 2) [38,39].

The temporal and predictive relationships between UO, 
Table 2. Studies exploring the relationships between AKI, UO, and mortality since 2008

\begin{tabular}{|c|c|c|c|}
\hline Study & Design & Population & Finding \\
\hline $\begin{array}{l}\text { Barrantes et al. } \\
\text { (2008) [38] }\end{array}$ & $\begin{array}{l}\text { Retrospective single-center } \\
\text { observational study }\end{array}$ & $\begin{array}{l}381 \text { Adult medical ICU } \\
\text { patients }\end{array}$ & $\begin{array}{l}\text { Independent association between any definitions of AKI and mortality, not explicit in the } \\
\text { variables adjusted for. Note excluding the requirement for adequate fluid challenge drops } \\
\text { the strength of the association; not explicitly tested if this is a function of sCr dilution, UO } \\
\text { response to filling, etc. }\end{array}$ \\
\hline $\begin{array}{l}\text { Joannidis et al. } \\
\text { (2009) [40] }\end{array}$ & $\begin{array}{l}\text { Post-hoc retrospective multi- } \\
\text { center observational study }\end{array}$ & $\begin{array}{l}\text { 14,356 Adult ICU patients, } \\
\text { from the SAPS-3 } \\
\text { database }\end{array}$ & 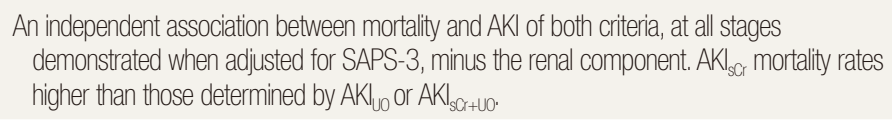 \\
\hline $\begin{array}{l}\text { Morgan and Ho } \\
\text { (2010) [39] }\end{array}$ & $\begin{array}{l}\text { Retrospective single-center } \\
\text { observational study }\end{array}$ & $\begin{array}{l}228 \text { Adult ICU patients } \\
\text { with RIFLE-FAKI }\end{array}$ & $\begin{array}{l}\text { Independent association between oliguric AKI status and mortality on multivariable regression } \\
\text { when adjusted for age, baseline creatinine, vasoactive use, total dose of furosemide used, } \\
\text { and the cause of AKl. }\end{array}$ \\
\hline $\begin{array}{l}\text { Prowle et al. } \\
\text { (2011) [4] }\end{array}$ & $\begin{array}{l}\text { Prospective multi-center } \\
\text { observational study }\end{array}$ & 239 Adult ICU patients & $\begin{array}{l}\text { In patients without AKI and periods of oliguria, the subsequent risk of AKI was associated with } \\
\text { duration of oliguria, with } 4 \text { hours being the optimum cutoff, but all values below } 12 \text { hours } \\
\text { having limited utility due to low positive likelihood ratio. Patients with AKI and oliguria more } \\
\text { likely to receive intervention in the form of fluids or diuretics. }\end{array}$ \\
\hline $\begin{array}{r}\text { Macedo et al. } \\
\text { (2011) [41] }\end{array}$ & $\begin{array}{l}\text { Prospective single-center } \\
\text { observational study }\end{array}$ & $\begin{array}{l}317 \text { Adult surgical ICU } \\
\text { patients }\end{array}$ & $\begin{array}{l}\text { Independent associations between all forms of AKI, with OR greater for forms incorporating } \\
\text { UO, and ICU mortality when adjusted for age, cumulative FB (from ICU admission to the day } \\
\text { of AKI diagnosis), sepsis, and need for ventilation. Increased sensitivity using fixed or moving } \\
6 \text { hours block analyses for oliguria when compared to consecutive measurement. }\end{array}$ \\
\hline $\begin{array}{l}\text { Mandelbaum } \\
\text { et al. }(2013 \text {, } \\
\text { 2011) [32,42] }\end{array}$ & $\begin{array}{l}\text { Retrospective single-center } \\
\text { observational study }\end{array}$ & $\begin{array}{l}\text { 14,524 Adult critically ill } \\
\text { patients, from the MIMIC- } \\
\text { II database }\end{array}$ & $\begin{array}{l}\text { UO superior at predicting outcome in all classes of AKIN AKI than sCr criteria with appropriately } \\
\text { adjusted AUROC within the boundaries of the dataset; no reclassification statistics presented. } \\
\text { Significant increases in the adjusted and predicted mortality and RRT rates were observed } \\
\text { with oliguria, in a time and intensity-dependent fashion. Beyond } 24 \text { hours the risks of } \\
\text { mortality and RRT became independent of oliguria. }\end{array}$ \\
\hline $\begin{array}{l}\text { Han et al. (2012) } \\
\text { [43] }\end{array}$ & $\begin{array}{l}\text { Retrospective single-center } \\
\text { observational study }\end{array}$ & 1,625 Adult ICU patients & $\begin{array}{l}\text { Development of AKl Lo apparently a severity-dependent predictor of up to 3-year mortality, on } \\
\text { minimally adjusted Cox regression. }\end{array}$ \\
\hline $\begin{array}{l}\text { Wlodzimirow et } \\
\text { al. (2012) [44] }\end{array}$ & $\begin{array}{l}\text { Prospective single-center } \\
\text { observational study }\end{array}$ & 260 Adult ICU patients & 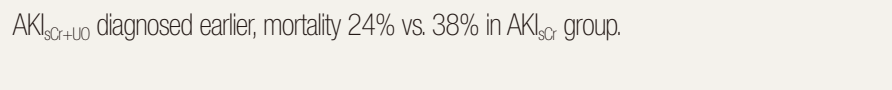 \\
\hline $\begin{array}{l}\text { Md Ralib et al. } \\
\text { (2013) [28] }\end{array}$ & $\begin{array}{l}\text { Post-hoc analysis of a } \\
\text { prospective single-center } \\
\text { observational study }\end{array}$ & $\begin{array}{l}725 \text { Adult ICU patients, } \\
72 \% \text { developing AKI }\end{array}$ & $\begin{array}{l}\text { UO thresholds of }<0.3 \mathrm{ml} / \mathrm{kg} / \mathrm{h} \text { independently associated with mortality after adjusting for } \\
\text { age, weight, illness severity, vasopressor use, fluid balance, presence of AKI or dialysis, and } \\
\text { baseline creatinine. }\end{array}$ \\
\hline $\begin{array}{l}\text { Leedahl et al. } \\
\text { (2014) [33] }\end{array}$ & $\begin{array}{l}\text { Retrospective single-center } \\
\text { observational study }\end{array}$ & $\begin{array}{l}390 \text { Adult ICU patients } \\
\text { with septic shock }\end{array}$ & $\begin{array}{l}\text { Consecutive hours of oliguria independently associated with development of stage I//II AKI; 3-5 } \\
\text { hours of consecutive oliguria greatest predictive power. }\end{array}$ \\
\hline $\begin{array}{l}\text { Kellum et al. } \\
\text { (2015) [45] }\end{array}$ & $\begin{array}{l}\text { Retrospective single-center } \\
\text { observational study }\end{array}$ & $\begin{array}{l}32,045 \text { Adult critically ill } \\
\text { patients }\end{array}$ & 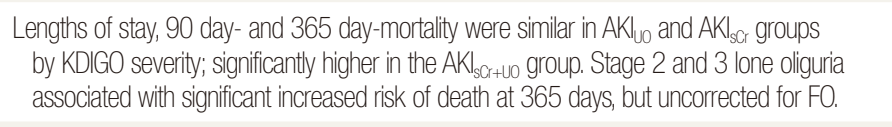 \\
\hline $\begin{array}{l}\text { Qin et al. (2016) } \\
\text { [46] }\end{array}$ & $\begin{array}{l}\text { Post-hoc analysis of data from } \\
\text { a multi-center prospective } \\
\text { observational study }\end{array}$ & 1,058 Adult ICU patients & 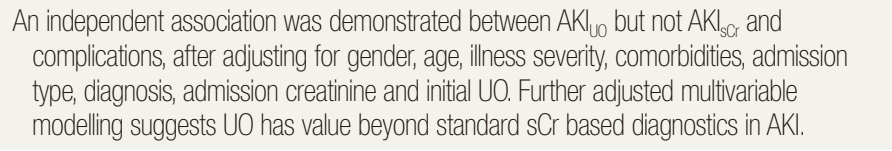 \\
\hline $\begin{array}{l}\text { Vaara et al. } \\
\text { (2015) [35] }\end{array}$ & $\begin{array}{l}\text { Post-hoc analysis of multi-center } \\
\text { prospective observational } \\
\text { study }\end{array}$ & 2,160 Adult ICU patients & $\begin{array}{l}\text { An independent association was demonstrated between UO of differing intensity and duration } \\
\text { and AKI, after adjusting for age, sex, illness severity, vasoactive or diuretic use, and FO. } \\
\text { An independent association was demonstrated between UO of differing intensity and } \\
\text { duration, and 90-day mortality, after adjusting for age, sex, illness severity, vasoactive or } \\
\text { diuretic use, RRT, and FO. } \\
\text { In patients without AKI and isolated oliguria alone, after adjusting for FO\%, diuretics, } \\
\text { vasoactive medication, illness severity, age, sex and diagnostic group, an independent } \\
\text { association between a UO of } 0.1 \text { to }<0.3 \mathrm{ml} / \mathrm{kg} / \mathrm{h} \text { for }>6 \text { hours was demonstrated with } \\
\text { 90-day mortality. }\end{array}$ \\
\hline
\end{tabular}

AKI: acute kidney injury; UO: urine output; ICU: intensive care unit; sCr: serum creatinine concentration; SAPS: Simplified Acute Physiology Score; AKI scr: AKI defined by sCr criteria; AKI uo: AKI defined by urinary criteria; $\mathrm{AKI}_{\mathrm{scr}+\mathrm{u} \text { o: }}$ AKI defined by both urinary and sCr criteria; RIFLE: Risk, Injury, Failure, Loss, End-Stage Renal Failure; OR: odds ratio; FB: fluid balance; MIMIC: multiparameter intelligent monitoring in intensive care database; AKIN: Acute Kidney Injury Network; AUROC: area under the receiver operating curve; RRT: renal replacement therapy; KDIGO: Kidney Disease: Improving Global Outcomes; FO: fluid overload. 
AKIN AKI and patient-centered outcomes were explored in a prospective single-center observational study of 317 adult surgical ICU patients from the United States, $10.7 \%$ with CKD. When divided into patients without $\mathrm{AKI}$, with lone $\mathrm{AKI}_{\mathrm{sCr}}$, lone $\mathrm{AKI}_{\mathrm{UO}}$ or $\mathrm{AKI}$ defined by both $\mathrm{sCr}$ and $\mathrm{UO}$ criteria $\left(\mathrm{AKI}_{\mathrm{sCr}+\mathrm{UO}}\right)$, groups significantly differed by age, body mass index, presence of comorbidities, sepsis, hypotension, ventilation status, acidbase status and nephrotoxin exposure, with the $\mathrm{AKI}_{\mathrm{SCr}+\mathrm{UO}}$ group having the highest number of those exposed. Fluid balance details were not presented. Independent associations were demonstrated between all definitions of AKI, irrespective of type, and ICU mortality when adjusted for age, cumulative fluid balance from ICU admission to the day of AKI diagnosis, sepsis, and need for ventilation, but not illness severity. Referent to patients without AKI, the odds ratio (OR) for mortality was higher in patients with $\mathrm{AKI}_{\mathrm{UO}}$ compared to $\mathrm{AKI}_{\mathrm{SCr}}(\mathrm{OR}, 5.09$ vs. 2.96), but highest in those with $\mathrm{AKI}_{\mathrm{sCr}+\mathrm{UO}}(\mathrm{OR}, 5.56)$ [41].

In a secondary analysis of 1,058 adult ICU patients, 55.4\% developing AKI, $12.8 \%$ requiring RRT and, 4.8\% with CKD from 22 Chinese centers, the additional and independent diagnostic and prognostic value of the KDIGO AKI $\mathrm{UO}_{\mathrm{UO}}$ over the $\mathrm{AKI}_{\mathrm{SCr}}$ criteria were assessed. Despite reporting changes in the incidence of AKI when using either $\mathrm{UO}$ and serum creatinine criteria $\mathrm{AKI}_{\mathrm{SCr}+\mathrm{UO}}$, no reclassification statistics were offered. KDIGO $\mathrm{AKI}_{\mathrm{sCr}}$ criteria could be applied across the entirety of the admission, not just the 7 days they are described and validated for. Oddly, patients requiring RRT were classified by UO or sCr changes, not as stage $3 \mathrm{AKI}$. An independent association was demonstrated between $\mathrm{AKI}_{\mathrm{UO}}$ (OR, 2.89; 95\% confidence interval [CI], 1.96 to $4.25, \mathrm{P}<0.001$ ), but not $\mathrm{AKI}_{\mathrm{sCr}}$, (OR, 1.32; 95\% CI, 0.9 to $\left.1.94 ; \mathrm{P}=0.152\right)$, and hospital mortality, after adjusting for gender, age, illness severity, comorbidities, admission type, diagnosis, admission creatinine and initial UO, and complications, although the lack of reported collinearity between diagnoses raises methodological concerns. Further adjusted multivariable modelling suggests UO has value beyond standard $\mathrm{sCr}$ based diagnostics in $\mathrm{AKI}$, but the magnitude seems out of keeping with the other literature [46].

In a prospective single-center observational study from a Dutch academic ICU, 260 adult ICU patients, 57\% developing AKI, $6 \%$ with $\mathrm{CKD}$, the effect of including UO criteria to $\mathrm{sCr}$ criteria on the incidence and time to diagnosis of AKI were explored. Cumulative fluid balance was higher in the RIFLE $\mathrm{AKI}_{\mathrm{sCr}+\mathrm{UO}}$ group from AKI diagnosis; this difference was statistically significant over days 1-3 postdiagnosis. Fluid balance data was not used to adjust $\mathrm{sCr}$, or in modelling. By day 7, RIFLE $\mathrm{AKI}_{\mathrm{sCr}+\mathrm{UO}}$ was much more common than $\mathrm{AKI}_{\mathrm{sCr}}(80.8 \%$ vs. $41.5 \%$ ), was diagnosed earlier and associated with a lower mortality ( $24 \%$ vs. $38 \%$ ) [44].

In the study from New Zealand mentioned earlier, where $\mathrm{sCr}$ had been corrected for fluid balance, KDIGO AKI status by both $\mathrm{UO}$ and $\mathrm{sCr}$ criteria were identified: the incidence of $\mathrm{KDIGO} \mathrm{AKI}_{\mathrm{sCr}+\mathrm{UO}}$ was $72 \%$, compared to $38 \%$ for $\mathrm{AKI}_{\mathrm{sCr}}$ alone. Referent to patients with no form of AKI, the odds of dying or requiring RRT were similar in the $\mathrm{AKI}_{\mathrm{SCr}}$ and $\mathrm{AKI}_{\mathrm{UO}}$ groups (OR, 1.34 vs. 1.36), but significantly higher in the $\mathrm{AKI}_{\mathrm{sCr}+\mathrm{UO}}$ group (OR, $3.62)$.

In a retrospective single-center observational study from a US teaching hospital of 14,524 adult critically ill patients, $57 \%$ of who developed AKIN AKI, the ability of the $\mathrm{sCr}$ and UO AKIN criteria to predict morbidity and mortality were explored. UO criteria were superior at predicting outcome in all classes of AKIN AKI than $\mathrm{sCr}$ criteria with appropriately adjusted AUROC analysis within the boundaries of the dataset; however, no reclassification statistics were presented, which would probably have been the most appropriate method of comparing multivariable AUROC models [42].

The largest study to date explored the relationships between severity and duration of KDIGO $\mathrm{AKI}_{\mathrm{SC}}, \mathrm{AKI}_{\mathrm{UO}}$, renal morbidity, and mortality in a large retrospective single-center observational study of 32,045 adult critically ill patients.

The mean fluid volume received over the first 24 hours varied significantly by KDIGO AKI status, with AKI-free patients receiving $3.8 \pm 3.1 \mathrm{~L}$; KDIGO AKI $\mathrm{UO}_{\mathrm{UO}}$ patients 4.1 
$\pm 3.5 \mathrm{~L}$; KDIGO $\mathrm{AKI}_{\mathrm{sCr}}$ patients $4.4 \pm 3.9 \mathrm{~L}$; and patients with KDIGO AKI by both $\mathrm{sCr}$ and UO criteria $\left(\mathrm{AKI}_{\mathrm{sCr}+\mathrm{UO}}\right)$ received $5 \pm 5 \mathrm{~L}$ of intravenous fluid, although $\mathrm{sCr}$ measurements were unadjusted for fluid balance. Patients with $\mathrm{AKI}_{\mathrm{sCr}+\mathrm{UO}}$ were more likely to have sepsis and require vasopressors, those with $\mathrm{AKI}_{\mathrm{sCr}}$ had higher baseline sCr and $\mathrm{CKD}$, and those with $\mathrm{AKI}_{\mathrm{UO}}$ more likely to have had major surgery. Lengths of stay, 90-day and 365-day mortality were similar in $\mathrm{AKI}_{\mathrm{SCr}}$ and $\mathrm{AKI}_{\mathrm{UO}}$ groups by KDIGO severity, but significantly higher in the $\mathrm{AKI}_{\mathrm{SCr}+\mathrm{UO}}$ group [45].

Despite these convincing relationships between oliguria and mortality in the context of AKI, no study links urinary staging to $\mathrm{sCr}$ staging, nor explores the possibilities for "backwards classification"- - using large datasets to identify patients with severe $\mathrm{AKI}_{\mathrm{sCr}}$, RRT or death as a starting point, then determining the haemodynamic and demographic factors which would make associated proximate episodes of oliguria clinically significant. This information could lead to more robust definitions of $\mathrm{AKI}_{\mathrm{UO}}$, or help define the phenotypes of clinically important types of AKI.

\section{Fluid Accumulation: A Forgotten Mediator?}

A standard clinical response to oliguria is the administration of additional intravenous fluid to correct true, relative or perceived hypovolaemia $[47,48]$. Moreover, routine maintenance and carrier fluid administrations may not be altered. However, it has never been determined if fluid accumulates in such circumstances because of treatment, or because of a failure of excretion, though it is likely to be a combination of both. Under these circumstances fluid accumulation could influence the relationship between AKI and mortality in many different ways (Figure 2) [49-51].

There is an evolving stream of evidence from the critical care literature that fluid accumulation and fluid overload modify the relationship between AKI and mortality

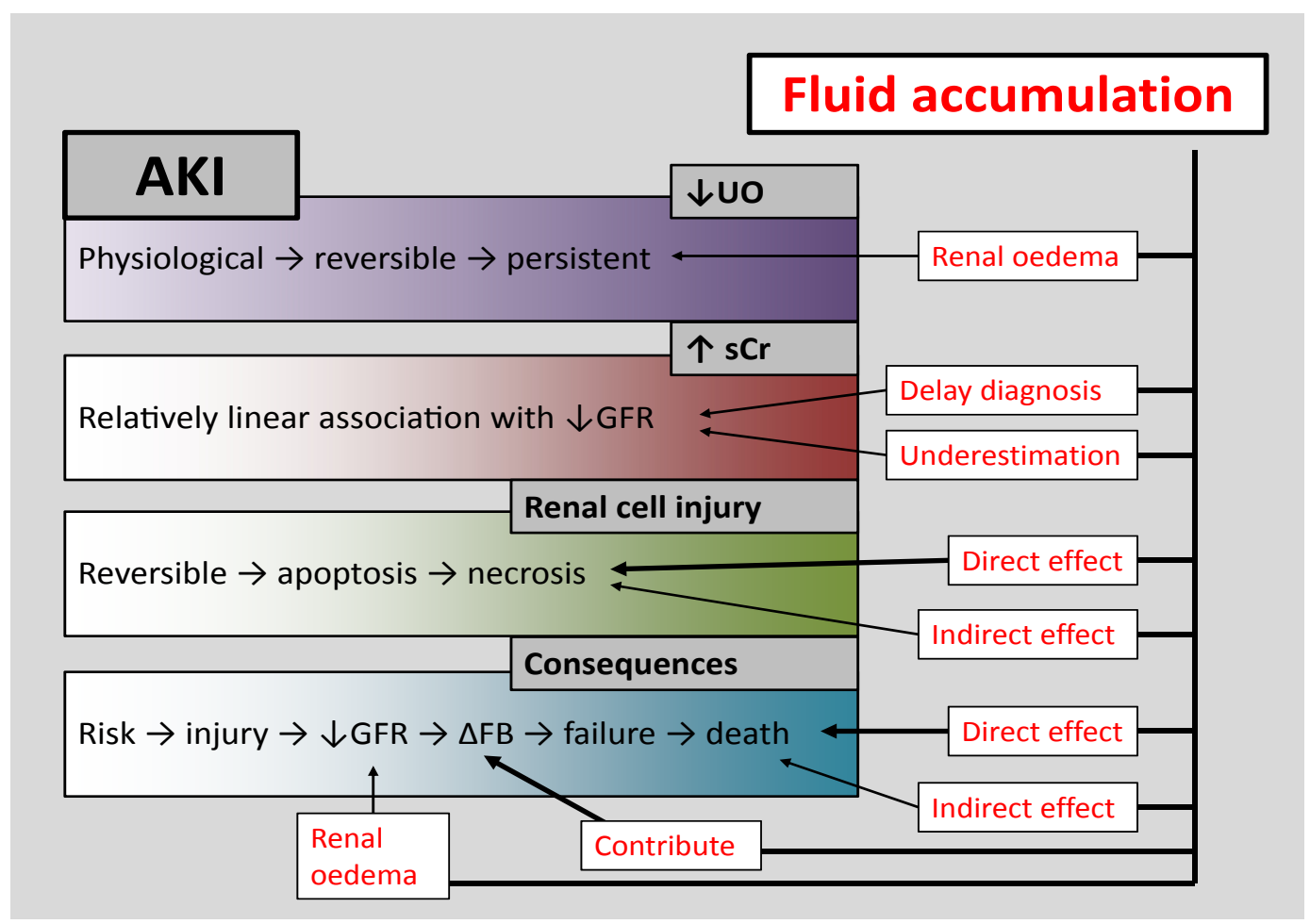

Figure 2. The complex relationship between acute kidney injury, fluid accumulation, and outcome. AKl: acute kidney injury; U0: urine output; sCr: serum creatinine; GFR: glomerular filtration rate; $\Delta \mathrm{FB}$ : change in fluid balance. 
Table 3. Studies exploring the relationships between AKI, oliguria, fluid balance, and mortality

\begin{tabular}{|c|c|c|c|}
\hline Study & Design & Population & Findings \\
\hline $\begin{array}{l}\text { PICARD }(2004 \\
\text { 2009, 2010) } \\
{[52-54]}\end{array}$ & $\begin{array}{l}\text { Data from the prospective } \\
\text { observational PICARD } \\
\text { study }\end{array}$ & $\begin{array}{l}610 \text { Adult ICU patients with } \\
\text { AKI, subgroup analysis in } \\
253 \text { patients with completes } \\
\text { sCr data }\end{array}$ & $\begin{array}{l}\text { Non-significant difference in FO between survivors and non-survivors once } \\
\text { adjusted for illness severity; significant linear trend for increasing mortality with } \\
\text { increasing proportion of days of RRT spent in FO. Up to } 25 \% \text { with delayed } \\
\text { recognition of AKI } \text { sGr using RIFLE criteria with use of sCr values not adjusted }_{\text {for cumulative FB. }}\end{array}$ \\
\hline $\begin{array}{l}\text { FACTT }(2006 \\
\text { 2011) [55-57] }\end{array}$ & $\begin{array}{l}\text { Post-hoc analyses of multi- } \\
\text { center randomised } \\
\text { controlled trial data from } \\
\text { the FACTT }\end{array}$ & $\begin{array}{l}306 \text { Critically ill adult ventilated } \\
\text { patients developing AKI }\end{array}$ & $\begin{array}{l}\text { Significant increase in incidence of AKIN AKI in liberal arm once adjusted for FB. } \\
\text { Mortality rates were lower for those who either had no AKI, or who no longer } \\
\text { had AKI after adjusting for FB; they were higher in those with AKI, or those } \\
\text { with AKI after adjusting for FB. Independent association between FB adjusted } \\
\text { AKI status and mortality on multivariable regression when adjusted for age, } \\
\text { gender, race, severity of illness, vasoactive use, and baseline sCr. Following } \\
\text { the development of AKI, FB was independently associated with an increased } \\
\text { risk of mortality, through multiple sensitivity analyses and across gender, fluid } \\
\text { strategy, early and late oliguria and severity of AKI groups. }\end{array}$ \\
\hline $\begin{array}{l}\text { RENAL Replacement } \\
\text { Therapy Study } \\
\text { Investigators, et al. } \\
\text { (2012) [58] }\end{array}$ & $\begin{array}{l}\text { Post-hoc analyses of multi- } \\
\text { center randomised } \\
\text { controlled trial data from } \\
\text { the RENAL trial }\end{array}$ & $\begin{array}{l}\text { 1,453 Critically ill adult } \\
\text { patients with AKI requiring } \\
\text { RRT }\end{array}$ & $\begin{array}{l}\text { Independent association between negative mean daily FB in ICU and 90- } \\
\text { day mortality in critically ill patients requiring RRT, persisting after extensive } \\
\text { adjustment and sensitivity analyses, including propensity score analysis. }\end{array}$ \\
\hline $\begin{array}{l}\text { Vaara et al. }(2012, \\
\text { 2015) }[34,35]\end{array}$ & $\begin{array}{l}\text { Post-hoc analysis of multi- } \\
\text { center prospective } \\
\text { observational study }\end{array}$ & 2,160 Adult ICU patients & $\begin{array}{l}\text { FO varies by AKI status, with AKI } \text { sCr+uo }_{\text {having the highest reported degree of FO. }} \text {. } \\
\text { In patients without AKI and isolated oliguria alone, after adjusting for FO\%, } \\
\text { diuretics, vasoactive medication, illness severity, age, sex and diagnostic } \\
\text { group, an independent association between a UO of } 0.1 \text { to }<0.3 \mathrm{ml} / \mathrm{kg} / \mathrm{h} \\
\text { for }>6 \text { hours was demonstrated with } 90 \text {-day mortality. In the } 283 \text { patients } \\
\text { requiring RRT, FO was independently associated with mortality following } \\
\text { adjustment for disease severity, time of RRT initiation, initial RRT modality, and } \\
\text { sepsis. }\end{array}$ \\
\hline $\begin{array}{l}\text { Teixeira et al. (2013) } \\
\text { [59] }\end{array}$ & $\begin{array}{l}\text { Post-hoc analysis of multi- } \\
\text { center prospective } \\
\text { observational study }\end{array}$ & $\begin{array}{l}132 \text { Critically ill patients with } \\
\text { AKI }\end{array}$ & $\begin{array}{l}\text { Both mean FB and mean UO, when adjusted for sepsis, age, gender, illness } \\
\text { severity, DM, CVD and hypertension, and interaction term of mean FB and } \\
\text { mean UO, were independently associated with mortality in patients with AKI. }\end{array}$ \\
\hline $\begin{array}{l}\text { Md Ralib et al. } \\
\text { (2013) [28] }\end{array}$ & $\begin{array}{l}\text { Post-hoc analysis of a } \\
\text { prospective single-center } \\
\text { observational study }\end{array}$ & 725 Adult ICU patients & $\begin{array}{l}\mathrm{AK}_{\mathrm{sc}} \text { calculated using values corrected for FB; no sensitivity analyses to assess } \\
\text { significance. }\end{array}$ \\
\hline $\begin{array}{l}\text { Garzotto et al. (2016) } \\
\text { [60] }\end{array}$ & $\begin{array}{l}\text { Multi-center prospective } \\
\text { observational study }\end{array}$ & 1,734 Adult ICU patients & $\begin{array}{l}\text { Examines volume accumulation kinetics as a surrogate of UO and differentiates } \\
\text { risk of mortality with rate of fluid accumulation by presence and severity } \\
\text { of AKI. Magnitude of FO was independently associated with mortality after } \\
\text { adjusting for illness severity and presence of AKI. The velocity of fluid } \\
\text { accumulation was independently associated with mortality, when adjusted for } \\
\text { illness severity, DM, CVD and hypertension, in patients with AKI or requiring } \\
\text { CRRT, but not those without AKI. }\end{array}$ \\
\hline $\begin{array}{l}\text { Neyra et al. (2016) } \\
\text { [61] }\end{array}$ & $\begin{array}{l}\text { Retrospective single-center } \\
\text { observational study }\end{array}$ & $\begin{array}{l}\text { 2,632 Adult ICU patients } \\
\text { with severe sepsis or septic } \\
\text { shock }\end{array}$ & $\begin{array}{l}\text { Cumulative FB and FO vary by AKI and CKD status. Independent association } \\
\text { per 1,000 ml of cumulative FB at } 72 \text { hours and mortality after extensive } \\
\text { appropriate adjustment in patients with and without AKI and CKD. }\end{array}$ \\
\hline $\begin{array}{l}\text { Thongprayoon et al. } \\
\text { (2016) [62] }\end{array}$ & $\begin{array}{l}\text { Retrospective single-center } \\
\text { observational study }\end{array}$ & 7,696 Adult ICU patients & $\begin{array}{l}\text { Correcting for FB reduces time to AKI detection. Independent association } \\
\text { demonstrated between AKI and mortality, when adjusted for age, ICU type, } \\
\text { illness severity and fluid balance. Adjustment for FB significantly improves } \\
\text { discriminatory ability of sCr to predict mortality. }\end{array}$ \\
\hline
\end{tabular}

AKl: acute kidney injury; PICARD: Program to Improve Care in Renal Disease; ICU: intensive care unit; sCr: serum creatinine concentration; FO: fluid overload; RRT: renal replacement therapy; AKIscr: AKI defined by sCr criteria; RIFLE: Risk, Injury, Failure, Loss, End-stage criteria; FB: fluid balance; FACTT: Fluids and Catheters Treatment trial; AKIN: Acute Kidney Injury Network criteria; RENAL: Randomised Evaluation of Normal vs. Augmented Level of Replacement Therapy study; AKI $_{s \mathrm{Cr}+\mathrm{U} \text { : }}$ AKI defined by both urinary and $\mathrm{SCr}$ criteria; UO: urine output; DM: diabetes mellitus; CVD: cardiovascular disease; CRRT: continuous renal replacement therapy; CKD: chronic kidney disease. 
(Table 3). In a post-hoc analysis of data from the Program to Improve Care in Renal Disease study, 253 adult ICU patients developing AKI, 52\% requiring RRT in ICU, $31 \%$ with CKD were identified with the aim of exploring the impact of fluid accumulation on the reported severity and time to diagnosis of $\mathrm{AKI}_{\mathrm{SCr}}$. With increasingly positive median cumulative fluid balances and increasing percentage underestimation of $\mathrm{sCr}$ monitoring being reported over the first 7 days of ICU admission, $25 \%$ of patients had delayed recognition of RIFLE R+ AKI, but there was no significant increase in mortality following correction of sCr. Unfortunately, no net reclassification statistics were presented [53].

In a post-hoc analysis of the North American Fluids and Catheters Treatment Trial (FACTT), 306 critically ill adult ventilated patients developing AKIN AKI within 48 hours of randomisation to pulmonary artery or central venous catheter and conservative/liberal fluid therapy were investigated to explore the relationships between fluid balance, diuretic therapy, and mortality. Conservative fluid therapy patients $(n=137)$ had lower albumin concentrations. They were also likely to have a day $7 \mathrm{cu}-$ mulative fluid balance of $-200 \mathrm{ml}$, compared to a $+7,000$ $\mathrm{ml}$ fluid balance in the fluid liberal group. The incidence of $\mathrm{AKI}_{\mathrm{sCr}}$ shifted from being higher in the conservative group $(57 \%$ vs. $51 \%, \mathrm{P}=0.04)$ to higher in the liberal group $(66 \%$ vs. $58 \%, \mathrm{P}=0.007)$ following correction for fluid balance. Mortality rates were lower for those who either had no $\mathrm{AKI}_{\mathrm{SCr}}$, or who no longer had $\mathrm{AKI}_{\mathrm{SCr}}$ after adjusting for fluid balance; they were higher in those with $\mathrm{AKI}_{\mathrm{sCr}}$, or those with $\mathrm{AKI}_{\mathrm{sCr}}$ after adjustment. An independent association was demonstrated between fluid balance-adjusted $\mathrm{AKI}_{\mathrm{sCr}}$ status and mortality on multivariable regression when adjusted for age, gender, race, illness severity, vasoactive medication use, and baseline sCr. Significant differences were demonstrated between groups in UOs and proportions of patients with oliguria [56].

The largest such study to date is a retrospective singlecenter observational study, also from the United States, in 7,696 adult ICU patients, $43 \%$ with AKI and $27 \%$ with
CKD, performed with the aim of evaluating the effects of adjusting for fluid balance on the incidence and sever-

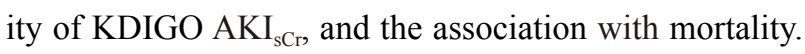
The median cumulative fluid balance over admission in this is population was $2.3 \pm 5.4 \mathrm{~L}$. After correction for fluid balance, the incidence of $\mathrm{AKI}_{\mathrm{SCr}}$ significantly increased from $24.3 \%$ to $25.3 \%(\mathrm{P}<0.001)$. A similar relationship between 60 -day mortality and $\mathrm{AKI}_{\mathrm{SCr}}$ diagnosis precorrection and postcorrection for fluid accumulation following adjustment for fluid balance, age, ICU type, and illness severity was demonstrated as in the FACTT cohort. The discriminatory power of $\mathrm{sCr}$ as a predictor of subsequent 60-day mortality in this cohort improved on adjustment for fluid balance, as demonstrated by a statistically significant increase in the AUROC from 0.68 to 0.7 $(\mathrm{P}=0.001)$ [62]

It is unclear whether fluid balance is a confounder of the relationship between AKI and mortality, having a direct, independent relationship with both the risk of developing renal dysfunction and death, or whether it lies on the causal pathway and therefore acts as a mediator of this relationship. Fluid administration is a routine intervention in the face of oliguria, but with limited evidence of generating a successful physiological response. Fluid accumulation can lead to organ oedema. The kidney is an encapsulated organ. Increased tissue volume leads to increased resistance to venous return, with subsequent reductions in glomerular filtration rate, and potentially contributing to renal ischaemia in severe cases [63-66]. Oedema of other organ systems such as the brain, heart and lungs may directly, via reductions in cardiac output or oxygen delivery, or indirectly via neurohormonal cross talk, contribute to AKI; such pathophysiological changes may also have a direct impact on mortality $[67,68]$. By increasing total body water and circulating volume, fluid accumulation could dilute serial creatinine measurements, masking the true severity of the underlying renal dysfunction $[53,62]$. While these relationships are of interest in the prognostication and management of critically ill patients with AKI, there are larger implications given the methods we use to predict outcome at a cohort, unit and 
Table 4. A summary of the renal domains of the major illness severity scores

\begin{tabular}{|c|c|c|c|c|c|c|}
\hline \multirow{2}{*}{\multicolumn{2}{|c|}{ Renal domain }} & \multicolumn{5}{|c|}{ Scoring system } \\
\hline & & APACHE II & APACHE III & SAPS II & SAPS 3 & $\mathrm{MPM}_{24}-\mathrm{III}$ \\
\hline \multirow[t]{7}{*}{$\mathrm{UO} \mathrm{ml} / 24 \mathrm{~h}$} & $\uparrow$ & & $\leq 399$ & & & \\
\hline & & & 400-599 & $<500$ & & $<450^{\mathrm{a}}$ \\
\hline & & & 600-899 & 500-999 & & \\
\hline & & & $900-1,499$ & & & \\
\hline & | & & 1,500-1,999 & & & \\
\hline & $0 \mathrm{pt}^{\mathrm{b}}$ & & 2,000-3,999 & $>1,000$ & & \\
\hline & $\downarrow$ & & $\geq 4,000$ & & & \\
\hline \multirow[t]{5}{*}{$\mathrm{sCr} \mu \mathrm{mol} / \mathrm{l}$} & $\uparrow$ & $>309.4$ & & & $>309.4$ & \\
\hline & & 176.8-309.4 & $\geq 172$ & & $176.8-309.4$ & \\
\hline & & 132.6-176.8 & 133-171 & & $106.1-176.8$ & $\geq 176.8$ \\
\hline & $0 \mathrm{pt}^{\mathrm{b}}$ & 53-132.6 & 44-132 & & $<106.1$ & \\
\hline & $\downarrow$ & $<53$ & $<43$ & & & \\
\hline \multirow[t]{2}{*}{ ARF } & & c & $s C r \geq 133$ & & & d \\
\hline & & & UO $<410$ & & & \\
\hline \multirow[t]{5}{*}{ Urea mmol/l } & $\uparrow$ & & $\geq 28.6$ & & & \\
\hline & & & $14.4-28.5$ & & & \\
\hline & & & $7.2-14.3$ & $\geq 30$ & & \\
\hline & & & $6.2-7.1$ & 10-29.9 & & \\
\hline & $0 \mathrm{pt}^{\mathrm{t}}$ & & $\leq 6.1$ & $\leq 10$ & & \\
\hline
\end{tabular}

APACHE: Acute Physiology and Chronic Health Evaluation; SAPS: Simplified Acute Physiology Score; MPM 24: 24-hour score of the Mortality Probability Model; UO: urine output; sCr: serum creatinine concentration; ARF: acute renal failure, $\mathrm{sCr} \pm \mathrm{UO}$ definitions .

${ }^{a}$ Original derivation $<150 \mathrm{ml} / 8 \mathrm{~h}$; ${ }^{b}$ Range at which no points are accrued towards illness severity score - effectively the normal range for the cohort; ${ }^{\mathrm{C} N o}$ criteria given, renal contribution doubled if deemed present; 'Acute tubular necrosis or other causes excludes prerenal causes.

national level using illness severity scoring systems.

\section{IIIness Severity Scores}

Illness severity scoring systems, used to predict the outcomes of groups of patients in the ICU, are one reason why the disciplines of intensive care medicine, epidemiology and statistics travel so well together. While not useful for individual patient prognostication or decisionmaking, they are very useful in predicting mortality at a cohort level, standardising patient groups for illness severity for the purposes of research, and standardising mortality rates reported by individual ICUs to allow for performance monitoring and benchmarking [69]. Three of the most commonly used such models include the
Mortality Probability Model (MPM), Simplified Acute Physiology Score (SAPS), and the APACHE classification. All three of these models include renal characteristics in the form of $\mathrm{sCr}$, urea or $\mathrm{UO}$ measurements, acknowledging their potential contribution to patient outcome. However, all do so in different ways (Table 4).

\section{Mortality Probability Model}

The MPM is most commonly used in the US critical care literature [70]. Initially described in the 1980s using a single-center cohort, it has recently undergone its third iteration, this time based on a cohort of almost 125,000 patients from 135 ICUs in 98 centers in America [71]. As with the other models, its predictive performance has 
improved as it is has been serially derived from larger cohorts [72].

The $\mathrm{MPM}_{0}$ is generally based on parameters gathered on, or over the first hour of ICU admission, and so relies on preceding diagnoses and immediate physiology to predict subsequent ICU outcomes, although extended models taking into account physiological and clinical variables at 24 hours $\left(\mathrm{MPM}_{24}\right), 48$ hours $\left(\mathrm{MPM}_{48}\right)$, and 72 hours $\left(\mathrm{MPM}_{72}\right)$ also exist. Parameters are organised into categorical binary responses, offering little granularity. No studies have compared the MPM to other, routinely used models within the critically ill Australian and New Zealand (ANZ) population.

The renal component of the $\mathrm{MPM}_{0}$-III is based on the presence or absence of $\mathrm{CKD}$, determined as $\mathrm{sCr} \geq 176.8$ $\mu \mathrm{mol} / \mathrm{l}$, or ARF, defined as a diagnosis of acute tubular necrosis or acute on chronic renal failure, but not acute prerenal failure (Table 4) [71]. The specifics of diagnosis are not referenced [71,73]. As $\mathrm{MPM}_{0}$ is calculated using only variables collected over the first hour of admission, it is unlikely to provide sufficient information to explore the relationships between fluid administration, fluid balance, UO, evolving AKI and mortality. The $\mathrm{MPM}_{24-72}-\mathrm{II}$ models incorporate postadmission variables over 24-72 hours, and include oliguria as a component, with a UO of $<150 \mathrm{ml}$ over 8 hours having an adjusted OR for death of 2.3 (95\% CI, 1.9 to 2.7) [73]. No fluid administration or fluid balance variables were incorporated into the modelling during any of the three iterations, to our knowledge $[71,73]$.

\section{Simplified Acute Physiology Score}

The SAPS was initially designed as a risk stratification tool as a weighted score based on expert opinion in a group of 679 patients from eight French ICUs [74]. Based on the worst value recorded in the first 24 hours of ICU admission in a collection of 14 variables, each scoring 0 to 4 points on the basis of magnitude of derangement, it was never designed to predict mortality. SAPS II, derived by logistic regression from over 13,000 patients from 137 ICUs from 12 countries in North America and Europe, incorporated acute physiology, surgical status, and chronic illnesses, but failed to account for the effect of acute diagnoses.

The renal component of SAPS 2, allocates points to derangements of serum urea concentration, and UO. In the SAPS 2 cohort, no relationship was demonstrated between mortality and $\mathrm{sCr}$ in the first 24 hours of ICU admission, or with the diagnosis of renal failure [75]. In general, SAPS II failed to calibrate to populations outside that from which it was derived [76].

Confusingly, SAPS 3 is a completely new model, specifically designed to identify at ICU admission, those at greatest risk of death, and the 20 component variables are collected over the first hour of ICU admission [77,78]. Prediction modelling was carried out in 16,784 patients from 303, mainly European, ICUs [78]. Though an international cohort, the North, Central and Southern American cohorts were small, and there was no evidence of significant participation by African or Asian centers [78]. Statistical modelling for the SAPS 3 cohort was complex; of potential renal variables only $\mathrm{sCr}$ is included (Table 4) [77]. Neither model incorporates measures of fluid accumulation, nor other fluid volume variables, nor is their evidence of their consideration for inclusion $[75,77]$.

\section{Acute Physiology and Chronic Health Evaluation}

The APACHE classification system was first described in 1981, and was based on 700 patients from two ICUs in the United States [79]. The second iteration, APACHE II, followed in 1985, and was based on almost 6,000 patients from 13 ICUs in the United States [80]. The variables comprising both APACHE and APACHE II were selected and weighted by a panel of experts rather than logistic regression, an approach that followed in 1991 with the advent of APACHE III [20]. APACHE III 
was derived from extensive multiple logistic regression analysis in a cohort of 17,440 patients from 40 US ICUs. The 10th iteration of the APACHE III prediction model, APACHE III-j, was released into the public domain in 2002 , and has formed the basis of mortality prediction for benchmarking and standardisation in ANZ until very recently [81,82].

Where APACHE II collects data on 17 variables, APACHE III requires more data collection, requiring information on 31. The APACHE scores capture patient status at the end of the first 24 hours in the ICU, with the worst value for each physiological variable being recorded over that time being assigned a weighted numerical value. Patients who were transferred from another site, who were readmissions, or spent less than 4 hours in the ICU were excluded from the derivation work. In the APACHE system, points are allocated to derangements of serum urea and $\mathrm{sCr}$ concentration, and UO, with additional weight provided for the diagnosis of ARF, in APACHE III defined as a $\mathrm{sCr}>133 \mu \mathrm{mol} / \mathrm{l}$ and a UO $<410 \mathrm{ml}$ over 24 hours. Such a diagnosis adds an additional 10 points to an APACHE III score beyond those accumulated for acute physiological derangement; each increase in APACHE III score of 5 points is associated with an increase in the OR for mortality of 1.1 to 1.78 (Table 4) [20,80]. Neither model incorporates measures of fluid accumulation.

The APACHE IV score is of significantly increased complexity, requiring the collection of more than 140 variables [83]. While routine collection of this data may be possible in systems with appropriate information technology infrastructure, the benefits of increased granularity are unlikely to outweigh the costs of collection.

\section{ANZ Risk of Death Model}

In ANZ patient data suitable for calculating several illness severity scores, including SAPS II, and APACHE II and III, are routinely collected as part of an ongoing peer review, quality assurance and clinical governance program facilitated by the ANZ Intensive Care Society Centre for Outcome and Resource Evaluation (ANZICS CORE) in the form of the adult patient database. The additional information that would have to be collected to generate the APACHE IV score means that it is unlikely be implemented in ANZ [84]. Moreover, APACHE-IV is poorly calibrated for use in the Asia-Pacific region [85-87].

The ANZ Risk of Death (ANZROD) model is a series of predictive equations utilizing components of the APACHE III-j acute physiology and age scores, along with chronic health variables (as defined by APACHE II), need for mechanical ventilation, the source of ICU and hospital admission, if admission was for elective surgery, presence of a treatment limitation order, lead time to ICU admission, and the effect of the primary diagnosis from a list of 124 which included regional diagnoses distinct from the APACHE III-j definitions [20,84]. Significant statistical interactions were observed between APACHE III score, acute physiological scoring and diagnosis, and so separate models were created for each diagnostic group - cardiovascular surgical, other cardiovascular, respiratory, gastrointestinal, neurological, trauma, sepsis, and other, giving eight separate equations, as well as a combined equation to represent the cohort [84]. While based on data from over 450,000 admissions between 2004 and 2009 [84], it was recalibrated with more than 100,000 further admissions per year from 2012, in part to further validate the model, and in part to offset the timedependent drift in predictive accuracy $[69,82,88]$.

ANZROD was developed to be inclusive, and to be able to be applied to every adult patient - the only patients excluded were those admitted for palliative care or to facilitate organ donation [84]. It was based on the data already collected as part of an ongoing peer review, quality assurance and clinical governance program facilitated by ANZICS CORE [89]. Similar approaches building on established systems to develop locally relevant scores have been made in other jurisdictions [90].

The ANZROD effectively retains the renal components of APACHE III-j and data fluid administration and fluid balance variables are not used. Given that the AUROC 
for ANZROD in predicting hospital mortality is 0.902 in the ANZ population, it is likely to be a robust predictor of outcome in samples of patients from ANZ ICUs [69]. To improve on this already impressive predictive power would indicate that those variables had a strong independent association with mortality.

\section{Fluid Volume Variables and Mortality}

None of the currently extant major illness severity scoring systems or outcome prediction models use modern definitions of AKI or oliguria, or any values representative of fluid volumes variables. Moreover, none of the systems account for weight, or correct UO to the weightbased thresholds discussed above. It is uncertain if this is because they were examined at an early stage of the model building process and discarded, or if they failed to be considered at all. The second option is more likely given the notorious inaccuracy of pre-ICU fluid balance data, the original paradigms within which the models were constructed, the granularity of data available in large datasets, and the fact that large database cohort work is often done with patient groups already 3 to 5 years old, preventing immediate advances in information technology from being taken advantage of, while emphasising the temporal limitations of statistical prediction.

Indices of fluid administration and fluid balance are widely felt to be at least an indicator of illness severity, and may have an independent association with outcome [91,92]. Even if a direct relationship with mortality is not observed, then it is possible that fluid balance or fluid volume variables mediate the relationship between illness severity and mortality in the renal and respiratory physiological domains, or via the now anachronistic diagnosis of ARF $[93,94]$. This would make fluid administration and fluid balance an important, easily modifiable, potential therapeutic target for future investigation. The ANZROD offers a unique opportunity to explore the associations between illness severity, indices of renal function and fluid volume variables and mortality in critically ill patients in ANZ.

\section{Conclusions}

The current thresholds defining oliguria, while arbitrarily defined, have been demonstrated to have important relationships with the subsequent development of AKI and risk of mortality. However, studies relating absolute measurements, and measurements using ideal bodyweight to outcome are absent from the literature. The relationship between AKI and mortality is poorly explained by $\mathrm{sCr}$ alone, and it is likely that AKI syndromes presenting with oliguria represent both the least and most severe forms of renal dysfunction. Fluid accumulation appears to be an important mediator of the relationship between AKI, UO and mortality. Current illness severity scoring systems fail to take modern definitions of AKI and these complexities into account, and these relationships require exploration in large datasets before being prospectively validated in groups of critically ill patients from differing jurisdictions to improve prognostication and mortality prediction.

\section{Acknowledgments}

Avant Doctors-in-Training Research Scholarship supports Dr. Glassford. This review was supported by an unrestricted educational grant from the Austin Hospital Anaesthesia and Intensive Care Trust Fund.

Avant and the Austin Hospital Anaesthesia and Intensive Care Trust Fund played no role in preparation, review, or approval of the manuscript.

The authors would like to thank Dr. Johan Mårtensson and Dr. Suvi Vaara for their advice with the preparation of the final manuscript.

\section{ORCID}

$\begin{array}{ll}\text { Neil J. Glassford } & \text { https://orcid.org/0000-0003-1647-3745 } \\ \text { Rinaldo Bellomo } & \text { https://orcid.org/0000-0002-1650-8939 }\end{array}$ 


\section{References}

1. Eknoyan G. Origins of nephrology: hippocrates, the father of clinical nephrology. Am J Nephrol 1988;8:498-507.

2. Marketos SG, Eftychiadis AG, Diamandopoulos A. Acute renal failure according to ancient Greek and Byzantine medical writers. J R Soc Med 1993;86:290-3.

3. Kouba E, Wallen EM, Pruthi RS. Uroscopy by Hippocrates and Theophilus: prognosis versus diagnosis. J Urol 2007;177:50-2.

4. Prowle JR, Liu YL, Licari E, Bagshaw SM, Egi M, Haase M, et al. Oliguria as predictive biomarker of acute kidney injury in critically ill patients. Crit Care 2011;15:R172.

5. Chesley LC. The validity of the calculation of standard urea clearances from low urine volumes. J Clin Invest 1937;16:653-6.

6. Chesley LC. Renal excretion at low urine volumes and the mechanism of oliguria. J Clin Invest 1938;17:591-7.

7. Chesley LC. Urea excretion at low urine volumes: the calculation of "minimal" urea clearances. J Clin Invest 1938;17:119-23.

8. Chasis H, Smith HW. The excretion of urea in normal man and in subjects with glomerulonephritis. J Clin Invest 1938;17:347-58.

9. Gamble JL. The Harvey lectures, series XLIII, 19461947: physiological information gained from studies on the life raft ration. Nutr Rev 1989;47:199-201.

10. Creevy CD. Oliguria and anuria. Postgrad Med 1954; 16:456-8.

11. Hopper JJ, Partridge JW. Anuria and oliguria: a review of symptoms, pathologic physiology and mortality rates. Calif Med 1950;72:415-21.

12. Hopper JJ Jr, Partridge JW. Anuria and oliguria: treatment by conservative means, case report, with determination of blood volume and $\mathrm{Na} 24$ space. Calif Med 1950;73:42-53.

13. Hay EB. Experiences with anuria and oliguria. AMA
Arch Surg 1951;62:565-73.

14. Joekes AM. Discussion on anuria in medical conditions. Proc R Soc Med 1957;50:496-8.

15. Brooks DK. The modern treatment of anuria and oliguria. Postgrad Med J 1958;34:583-7.

16. Milne MD. Discussion on anuria in medical conditions. Proc R Soc Med 1957;50:493-6.

17. Hopkins RW, Sabga G, Bernardo P, Penn I, Simeone FA. Significance of post-traumatic and postoperative oliguria. Arch Surg 1963;87:320-30.

18. Harrington JT, Cohen JJ. Acute oliguria. N Engl J Med 1975;292:89-91.

19. Klahr S, Miller SB. Acute oliguria. N Engl J Med 1998;338:671-5.

20. Knaus WA, Wagner DP, Draper EA, Zimmerman JE, Bergner M, Bastos PG, et al. The APACHE III prognostic system: risk prediction of hospital mortality for critically ill hospitalized adults. Chest 1991;100:1619-36.

21. Schetz M, Hoste E. Understanding oliguria in the critically ill. Intensive Care Med 2016 Sep 12 [Epub]. https://doi.org/10.1007/s00134-016-4537-7.

22. Mathew OP, Jones AS, James E, Bland H, Groshong T. Neonatal renal failure: usefulness of diagnostic indices. Pediatrics 1980;65:57-60.

23. Gianantonio CA, Vitacco M, Mendilaharzu J, Mendilaharzu F, Rutty A. Acute renal failure in infancy and childhood: clinical course and treatment of 41 patients. J Pediatr 1962;61:660-78.

24. Akcan-Arikan A, Zappitelli M, Loftis LL, Washburn KK, Jefferson LS, Goldstein SL. Modified RIFLE criteria in critically ill children with acute kidney injury. Kidney Int 2007;71:1028-35.

25. Bezerra CT, Vaz Cunha LC, Libório AB. Defining reduced urine output in neonatal ICU: importance for mortality and acute kidney injury classification. Nephrol Dial Transplant 2013;28:901-9.

26. Bellomo R, Ronco C, Kellum JA, Mehta RL, Palevsky P; Acute Dialysis Quality Initiative workgroup. Acute renal failure--definition, outcome measures, animal models, fluid therapy and information 
technology needs: the Second International Consensus Conference of the Acute Dialysis Quality Initiative (ADQI) Group. Crit Care 2004;8:R204-12.

27. Legrand M, Payen D. Understanding urine output in critically ill patients. Ann Intensive Care 2011;1:13.

28. Md Ralib A, Pickering JW, Shaw GM, Endre ZH. The urine output definition of acute kidney injury is too liberal. Crit Care 2013;17:R112.

29. Waikar SS, Bonventre JV. Creatinine kinetics and the definition of acute kidney injury. J Am Soc Nephrol 2009;20:672-9.

30. Mehta RL, Kellum JA, Shah SV, Molitoris BA, Ronco C, Warnock DG, et al. Acute Kidney Injury Network: report of an initiative to improve outcomes in acute kidney injury. Crit Care 2007;11:R31.

31. Kellum JA, Lameire N; KDIGO AKI Guideline Work Group. Diagnosis, evaluation, and management of acute kidney injury: a KDIGO summary (part 1). Crit Care 2013;17:204.

32. Mandelbaum T, Lee J, Scott DJ, Mark RG, Malhotra A, Howell MD, et al. Empirical relationships among oliguria, creatinine, mortality, and renal replacement therapy in the critically ill. Intensive Care Med 2013;39:414-9.

33. Leedahl DD, Frazee EN, Schramm GE, Dierkhising RA, Bergstralh EJ, Chawla LS, et al. Derivation of urine output thresholds that identify a very high risk of AKI in patients with septic shock. Clin J Am Soc Nephrol 2014;9:1168-74.

34. Vaara ST, Korhonen AM, Kaukonen KM, Nisula S, Inkinen $\mathrm{O}$, Hoppu $\mathrm{S}$, et al. Fluid overload is associated with an increased risk for 90-day mortality in critically ill patients with renal replacement therapy: data from the prospective FINNAKI study. Crit Care 2012;16:R197.

35. Vaara ST, Parviainen I, Pettila V, Nisula S, Inkinen $\mathrm{O}$, Uusaro A, et al. Association of oliguria with the development of acute kidney injury in the critically ill. Kidney Int 2015 Sep 9 [Epub]. https://doi. org/10.1038/ki.2015.269.

36. Singbartl K, Kellum JA. AKI in the ICU: definition, epidemiology, risk stratification, and outcomes. Kidney Int 2012;81:819-25.

37. Murugan R, Kellum JA. Acute kidney injury: what's the prognosis? Nat Rev Nephrol 2011;7:209-17.

38. Barrantes F, Tian J, Vazquez R, Amoateng-Adjepong Y, Manthous CA. Acute kidney injury criteria predict outcomes of critically ill patients. Crit Care Med 2008;36:1397-403.

39. Morgan DJ, Ho KM. A comparison of nonoliguric and oliguric severe acute kidney injury according to the risk injury failure loss end-stage (RIFLE) criteria. Nephron Clin Pract 2010;115:c59-65.

40. Joannidis M, Metnitz B, Bauer P, Schusterschitz N, Moreno R, Druml W, et al. Acute kidney injury in critically ill patients classified by AKIN versus RIFLE using the SAPS 3 database. Intensive Care Med 2009;35:1692-702.

41. Macedo E, Malhotra R, Bouchard J, Wynn SK, Mehta RL. Oliguria is an early predictor of higher mortality in critically ill patients. Kidney Int 2011;80:760-7.

42. Mandelbaum T, Scott DJ, Lee J, Mark RG, Malhotra A, Waikar SS, et al. Outcome of critically ill patients with acute kidney injury using the Acute Kidney Injury Network criteria. Crit Care Med 2011;39:2659-64.

43. Han SS, Kang KJ, Kwon SJ, Wang SJ, Shin SH, Oh $\mathrm{SW}$, et al. Additional role of urine output criterion in defining acute kidney injury. Nephrol Dial Transplant 2012;27:161-5.

44. Wlodzimirow KA, Abu-Hanna A, Slabbekoorn M, Chamuleau RA, Schultz MJ, Bouman CS. A comparison of RIFLE with and without urine output criteria for acute kidney injury in critically ill patients. Crit Care 2012;16:R200.

45. Kellum JA, Sileanu FE, Murugan R, Lucko N, Shaw $\mathrm{AD}$, Clermont G. Classifying AKI by urine output versus serum creatinine level. J Am Soc Nephrol 2015;26:2231-8.

46. Qin JP, Yu XY, Qian CY, Li SS, Qin TH, Chen EZ, et al. Value of kidney disease improving global outcomes urine output criteria in critically ill patients: a secondary analysis of a multicenter prospective 
cohort study. Chin Med J (Engl) 2016;129:2050-7.

47. Bihari S, Prakash S, Bersten AD. Post resusicitation fluid boluses in severe sepsis or septic shock: prevalence and efficacy (price study). Shock 2013;40:28-34.

48. Bihari S, Teubner DJ, Prakash S, Beatty T, Morphett M, Bellomo R, et al. Fluid bolus therapy in emergency department patients: indications and physiological changes. Emerg Med Australas 2016;28:531-7.

49. Bagshaw SM, Brophy PD, Cruz D, Ronco C. Fluid balance as a biomarker: impact of fluid overload on outcome in critically ill patients with acute kidney injury. Crit Care 2008;12:169.

50. Payen D, de Pont AC, Sakr Y, Spies C, Reinhart K, Vincent JL, et al. A positive fluid balance is associated with a worse outcome in patients with acute renal failure. Crit Care 2008;12:R74.

51. Van Biesen W, Yegenaga I, Vanholder R, Verbeke F, Hoste E, Colardyn F, et al. Relationship between fluid status and its management on acute renal failure (ARF) in intensive care unit (ICU) patients with sepsis: a prospective analysis. J Nephrol 2005;18:54-60.

52. Bouchard J, Soroko SB, Chertow GM, Himmelfarb J, Ikizler TA, Paganini EP, et al. Fluid accumulation, survival and recovery of kidney function in critically ill patients with acute kidney injury. Kidney Int 2009;76:422-7.

53. Macedo E, Bouchard J, Soroko SH, Chertow GM, Himmelfarb J, Ikizler TA, et al. Fluid accumulation, recognition and staging of acute kidney injury in critically-ill patients. Crit Care 2010;14:R82.

54. Mehta RL, Pascual MT, Soroko S, Savage BR, Himmelfarb J, Ikizler TA, et al. Spectrum of acute renal failure in the intensive care unit: the PICARD experience. Kidney Int 2004;66:1613-21.

55. Grams ME, Estrella MM, Coresh J, Brower RG, Liu KD; National Heart, Lung, and Blood Institute Acute Respiratory Distress Syndrome Network. Fluid balance, diuretic use, and mortality in acute kidney injury. Clin J Am Soc Nephrol 2011;6:966-73.

56. Liu KD, Thompson BT, Ancukiewicz M, Steingrub JS, Douglas IS, Matthay MA, et al. Acute kidney injury in patients with acute lung injury: impact of fluid accumulation on classification of acute kidney injury and associated outcomes. Crit Care Med 2011;39:2665-71.

57. National Heart, Lung, and Blood Institute Acute Respiratory Distress Syndrome (ARDS) Clinical Trials Network, Wiedemann HP, Wheeler AP, Bernard GR, Thompson BT, Hayden D, et al. Comparison of two fluid-management strategies in acute lung injury. $\mathrm{N}$ Engl J Med 2006;354:2564-75.

58. RENAL Replacement Therapy Study Investigators, Bellomo R, Cass A, Cole L, Finfer S, Gallagher $\mathrm{M}$, et al. An observational study fluid balance and patient outcomes in the Randomized Evaluation of Normal vs. Augmented Level of Replacement Therapy trial. Crit Care Med 2012;40:1753-60.

59. Teixeira C, Garzotto F, Piccinni P, Brienza N, Iannuzzi M, Gramaticopolo S, et al. Fluid balance and urine volume are independent predictors of mortality in acute kidney injury. Crit Care 2013;17:R14.

60. Garzotto F, Ostermann M, Martin-Langerwerf D, Sanchez-Sanchez M, Teng J, Robert R, et al. The Dose Response Multicentre Investigation on Fluid Assessment (DoReMIFA) in critically ill patients. Crit Care 2016;20:196.

61. Neyra JA, Li X, Canepa-Escaro F, Adams-Huet B, Toto RD, Yee J, et al. Cumulative fluid balance and mortality in septic patients with or without acute kidney injury and chronic kidney disease. Crit Care Med 2016;44:1891-900.

62. Thongprayoon C, Cheungpasitporn W, Srivali N, Ungprasert P, Kittanamongkolchai W, Kashani K. The impact of fluid balance on diagnosis, staging and prediction of mortality in critically ill patients with acute kidney injury. J Nephrol 2016;29:221-7.

63. Boyd JH, Forbes J, Nakada TA, Walley KR, Russell JA. Fluid resuscitation in septic shock: a positive fluid balance and elevated central venous pressure are associated with increased mortality. Crit Care Med 2011;39:259-65.

64. Legrand M, Dupuis C, Simon C, Gayat E, Mateo 
J, Lukaszewicz AC, et al. Association between systemic hemodynamics and septic acute kidney injury in critically ill patients: a retrospective observational study. Crit Care 2013;17:R278.

65. Marik PE, Baram M, Vahid B. Does central venous pressure predict fluid responsiveness? A systematic review of the literature and the tale of seven mares. Chest 2008;134:172-8.

66. Wong BT, Chan MJ, Glassford NJ, Martensson J, Bion V, Chai SY, et al. Mean arterial pressure and mean perfusion pressure deficit in septic acute kidney injury. J Crit Care 2015;30:975-81.

67. Okusa MD. The changing pattern of acute kidney injury: from one to multiple organ failure. Contrib Nephrol 2010;165:153-8.

68. Virzì G, Day S, de Cal M, Vescovo G, Ronco C. Heart-kidney crosstalk and role of humoral signaling in critical illness. Crit Care 2014;18:201.

69. Paul E, Bailey M, Kasza J, Pilcher D. The ANZROD model: better benchmarking of ICU outcomes and detection of outliers. Crit Care Resusc 2016;18:25-36.

70. Higgins TL, Teres D, Nathanson B. Outcome prediction in critical care: the Mortality Probability Models. Curr Opin Crit Care 2008;14:498-505.

71. Higgins TL, Teres D, Copes WS, Nathanson BH, Stark M, Kramer AA. Assessing contemporary intensive care unit outcome: an updated Mortality Probability Admission Model (MPM0-III). Crit Care Med 2007;35:827-35.

72. Higgins TL, Kramer AA, Nathanson BH, Copes W, Stark M, Teres D. Prospective validation of the intensive care unit admission Mortality Probability Model (MPM0-III). Crit Care Med 2009;37:1619-23.

73. Lemeshow S, Teres D, Klar J, Avrunin JS, Gehlbach SH, Rapoport J. Mortality Probability Models (MPM II) based on an international cohort of intensive care unit patients. JAMA 1993;270:2478-86.

74. Le Gall JR, Loirat P, Alperovitch A, Glaser P, Granthil C, Mathieu D, et al. A simplified acute physiology score for ICU patients. Crit Care Med 1984;12:975-7.

75. Le Gall JR, Lemeshow S, Saulnier F. A new Simpli- fied Acute Physiology Score (SAPS II) based on a European/North American multicenter study. JAMA 1993;270:2957-63.

76. Capuzzo M, Moreno RP, Le Gall JR. Outcome prediction in critical care: the simplified acute physiology score models. Curr Opin Crit Care 2008;14:485-90.

77. Moreno RP, Metnitz PG, Almeida E, Jordan B, Bauer P, Campos RA, et al. SAPS 3: from evaluation of the patient to evaluation of the intensive care unit. Part 2: development of a prognostic model for hospital mortality at ICU admission. Intensive Care Med 2005;31:1345-55.

78. Metnitz PG, Moreno RP, Almeida E, Jordan B, Bauer P, Campos RA, et al. SAPS 3: from evaluation of the patient to evaluation of the intensive care unit. Part 1: objectives, methods and cohort description. Intensive Care Med 2005;31:1336-44.

79. Knaus WA, Zimmerman JE, Wagner DP, Draper EA, Lawrence DE. APACHE-acute physiology and chronic health evaluation: a physiologically based classification system. Crit Care Med 1981;9:591-7.

80. Knaus WA, Draper EA, Wagner DP, Zimmerman JE. APACHE II: a severity of disease classification system. Crit Care Med 1985;13:818-29.

81. Pilcher DV, Hoffman T, Thomas C, Ernest D, Hart GK. Risk-adjusted continuous outcome monitoring with an EWMA chart: could it have detected excess mortality among intensive care patients at Bundaberg Base Hospital? Crit Care Resusc 2010;12:36-41.

82. Paul E, Bailey M, Van Lint A, Pilcher V. Performance of APACHE III over time in Australia and New Zealand: a retrospective cohort study. Anaesth Intensive Care 2012;40:980-94.

83. Zimmerman JE, Kramer AA, McNair DS, Malila FM. Acute Physiology and Chronic Health Evaluation (APACHE) IV: hospital mortality assessment for today's critically ill patients. Crit Care Med 2006;34:1297-310.

84. Paul E, Bailey M, Pilcher D. Risk prediction of hospital mortality for adult patients admitted to Australian and New Zealand intensive care units: 
development and validation of the Australian and New Zealand Risk of Death model. J Crit Care 2013;28:935-41.

85. Lee H, Shon YJ, Kim H, Paik H, Park HP. Validation of the APACHE IV model and its comparison with the APACHE II, SAPS 3, and Korean SAPS 3 models for the prediction of hospital mortality in a Korean surgical intensive care unit. Korean J Anesthesiol 2014;67:115-22.

86. Mann SL, Marshall MR, Woodford BJ, Holt A, Williams AB. Predictive performance of Acute Physiological and Chronic Health Evaluation releases II to IV: a single New Zealand centre experience. Anaesth Intensive Care 2012;40:479-89.

87. Wong RS, Ismail NA, Tan CC. An external independent validation of APACHE IV in a Malaysian intensive care unit. Ann Acad Med Singapore 2015;44:127-32.

88. Pilcher D, Paul E, Bailey M, Huckson S. The Australian and New Zealand Risk of Death (ANZROD) model: getting mortality prediction right for intensive care units. Crit Care Resusc 2014;16:3-4.
89. Australian and New Zealand Intensive Care Society. CORE-adult patient database (APD) [Internet]. Carlton: Australian and New Zealand Intensive Care Society; 2016 [cited 2017 May 12]. Available from: http://www.anzics.com.au/pages/CORE/apd.aspx.

90. Harrison DA, Parry GJ, Carpenter JR, Short A, Rowan $\mathrm{K}$. A new risk prediction model for critical care: the Intensive Care National Audit \& Research Centre (ICNARC) model. Crit Care Med 2007;35:1091-8.

91. Bagshaw SM, Cruz DN. Fluid overload as a biomarker of heart failure and acute kidney injury. Contrib Nephrol 2010;164:54-68.

92. O'Connor ME, Prowle JR. Fluid overload. Crit Care Clin 2015;31:803-21.

93. Imai K, Keele L, Tingley D. A general approach to causal mediation analysis. Psychol Methods 2010;15:309-34.

94. Schortgen F, Charles-Nelson A, Bouadma L, Bizouard G, Brochard L, Katsahian S. Respective impact of lowering body temperature and heart rate on mortality in septic shock: mediation analysis of a randomized trial. Intensive Care Med 2015;41:1800-8. 